\title{
Efficacy and safety of recombinant human endostatin combined with radiotherapy or chemoradiotherapy in patients with locally advanced non-small cell lung cancer: a pooled analysis
}

\author{
Shu-Ling Zhang, Cheng-Bo Han, Li Sun, Le-Tian Huang and Jie-Tao Ma*
}

\begin{abstract}
Purpose: To assess the efficacy and safety of recombinant human endostatin in combination with radiotherapy (RT) or concurrent chemoradiotherapy (CCRT) in patients with locally advanced non-small cell lung cancer (LA-NSCLC).

Methods: We searched eligible literature in available databases using combinations of the following search terms: lung cancer, endostatin or endostar, radiotherapy or radiation therapy or chemoradiotherapy. The inclusion criteria were: prospective or retrospective (including single-arm) studies that evaluated the efficacy and safety of endostatin plus radiotherapy (ERT) or concurrent chemoradiotherapy (ECRT) in patients with LA-NSCLC. Primary outcomes included the following: objective response rate (ORR), local control rates (LCR), overall survival (OS), progression-free survival (PFS), and adverse events (AEs). Tests of heterogeneity, sensitivity, and publication bias were performed.

Results: A total of 271 patients with LA-NSCLC from 7 studies were enrolled, including six prospective trials and one retrospective study. The pooled median PFS was 11.3 months overall, 11.2 months in the ECRT group, and 11.8 months in the ERT group. Pooled median OS and ORR were 18.9 months and $77.2 \%$ overall, 18.4 months and $77.5 \%$ in the ECRT group, and 19.6 months and $76.1 \%$ in the ERT group, respectively. The incidences of major grade $\geq 3$ AEs for all patients, subgroups of ECRT and ERT were $10.9 \%$ vs $11.9 \%$ vs $9.4 \%$ for radiation pneumonitis, $11.6 \%$ vs $12.2 \%$ vs $9.4 \%$ for radiation esophagitis, $35.5 \%$ vs $43.4 \%$ vs 0 for leukopenia, $27.8 \%$ vs $40.7 \%$ vs $2.1 \%$ for neutropenia, and $10.5 \%$ vs $12.3 \%$ vs $2.1 \%$ for anemia.
\end{abstract}

Conclusions: Combined endostatin with RT or CCRT is effective and well tolerated in treating LA-NSCLC, and less toxicities occur. Further validation through prospective randomized control trials is required.

Keywords: Chemoradiotherapy, Endostatin, Non-small cell lung cancer, Radiotherapy

*Correspondence: ma_jt@126.com

Department of Oncology, Shengjing Hospital of China Medical University,

Shenyang 110004, China

C C The Author(s). 2020 Open Access This article is licensed under a Creative Commons Attribution 4.0 International License, which permits use, sharing, adaptation, distribution and reproduction in any medium or format, as long as you give appropriate credit to the original author(s) and the source, provide a link to the Creative Commons licence, and indicate if changes were made. The images or other third party material in this article are included in the article's Creative Commons licence, unless indicated otherwise in a credit line to the material. If material is not included in the article's Creative Commons licence and your intended use is not permitted by statutory regulation or exceeds the permitted use, you will need to obtain permission directly from the copyright holder. To view a copy of this licence, visit http://creativecommons.org/licenses/by/4.0/ The Creative Commons Public Domain Dedication waiver (http://creativecommons.org/publicdomain/zero/1.0/) applies to the data made available in this article, unless otherwise stated in a credit line to the data. 


\section{Introduction}

Lung cancer is the most common cancer type worldwide [1], and non-small cell lung cancer (NSCLC) is the most common form (80-85\%) [2]. At the time of initial diagnosis, approximately one-third of patients with NSCLC present with locally advanced NSCLC (LANSCLC) [3]. Furthermore, about 70\% of LA-NSCLCs are unresectable, and chemoradiotherapy (CRT) was the recommended standard care for these patients $[4,5]$. No significant progress in the treatment of LA-NSCLC was made for many years until the PACIFIC study confirmed that consolidation therapy with durvalumab (a monoclonal antibody that blocks interactions of programmed cell death ligand 1 with the PD- 1 receptor) further improved survival following CRT [6-8].

Previous studies indicated that a hypoxic tumor microenvironment contributes not only to resistance of tumor cells to chemoradiation but also promotes metastasis [9, 10], and tumor oxygenation is essential for effective application of radiotherapy (RT) or CRT [11]. Therefore, novel treatments that enhance radiosensitivity by improving the hypoxic microenvironment are urgently needed. Prior to the findings of the PACIFIC study, researchers explored whether patients with LA-NSCLC could benefit from anti-angiogenic drugs combined with RT or CRT. However, earlier studies showed that administration of bevacizumab along with thoracic RT led to a high incidence of pulmonary toxicity, including radiation pneumonitis, hemoptysis and tracheoesophageal fistulae, in patients with stage III NSCLC [12, 13]. Therefore, concurrent bevacizumab with thoracic RT is unlikely to be further pursued as a treatment option for stage III NSCLC.

Preclinical studies have demonstrated that endostatin (a broad-spectrum angiogenesis inhibitor) is able to normalize tumor vasculature, alleviate hypoxia and increase tumor sensitivity to radiation $[14,15]$. Several studies have indicated enhanced efficacy and tolerable toxicity of endostatin combined with thoracic RT or CRT for patients with LA-NSCLC [16-18]. However, the reported studies to date are mostly retrospective or single arm studies with limited patient enrolment. In the present study, we performed a pooled analysis to assess the clinical efficacy and safety of endostatin combined with RT or concurrent chemoradiotherapy (CCRT) in patients with LA-NSCLC.

\section{Materials and methods}

\section{Search strategy}

We conducted a systematic search for available articles, both in published and abstract forms of PubMed, OVID, Web of SCI, EMBASE, Google Scholar, Cochrane Library, Chinese National Knowledge Infrastructure, and Wanfang databases. The final literature search was performed on June 30, 2019, using the following search terms: "lung cancer" AND (endostatin OR endostar) AND (radiotherapy OR radiation therapy OR chemoradiotherapy). Manual updates of abstracts presented till the 2019 meetings, such as American Society of Clinical Oncology, European Society for Medical Oncology, World Conference of Lung Cancer, and American Society for Therapeutic Radiology and Oncology were additionally performed.

\section{Study selection and search strategy}

Studies that met the following inclusion criteria were included in the pooled analysis: 1) prospective or retrospective (including single-arm) studies that evaluated the efficacy and safety of endostatin plus radiotherapy (ERT) or concurrent chemoradiotherapy (ECRT) in patients with LA-NSCLC; 2) studies with primary outcomes reporting at least one of the following endpoints: objective response rate (ORR), progression-free survival (PFS) and overall survival (OS), and local control rates (LCR), or adverse events (AEs) based on Common Terminology Criteria for Adverse Events version 3.0 or 4.0; 3) number of cases included for study was $\geq 10 ; 4$ ) articles or abstracts were written in English. After the selection process, the remaining titles and abstracts were screened for relevance independently by two authors. Full-text articles and meeting abstracts were finally reviewed for all studies that met the inclusion criteria.

\section{Data extraction and quality assessment}

Data were extracted independently by two reviewers according to the inclusion criteria. Discrepancies were resolved by discussing with a third reviewer. Each reviewer extracted data including author name, the publication years of the studies, number of patients, patient characteristics, treatment regimen, radiotherapy dosage, the method of endostatin administration, ORR, PFS, OS, LCR and AEs. The Jadad scale [19] and Newcastle Ottawa Scale [20] were used to assess the quality of the included studies.

\section{Statistical analysis}

Statistical analyses were conducted using Comprehensive Meta-Analysis (version 3.0) software (Biostat Inc., NJ, USA). For dichotomous variables, such as OS rates, PFS rates, ORR, LCR and AEs, we calculated the raw proportion of events divided by the total number of clinically evaluable patients. Additionally, we calculated weighted pooled rates of events by the number of clinically evaluable patients using a random effects model to account for heterogeneity in study size and the large variations in proportion. Median pooled weighted OS and PFS were calculated with descriptive statistics. Subgroup 
analysis was performed per type of treatment regimen (ERT or ECRT).

\section{Publication bias and sensitivity analysis}

The potential for publication bias in reported ORR values was assessed by funnel plots, with the appropriate accuracy intervals. Sensitivity analyses were performed for the results for ORR based on the leave-one-out approach.

\section{Results}

\section{Literature search}

Figure 1 depicts a flowchart of the literature search procedure. Overall, 113 records were identified using the search strategy and 102 records excluded after screening the titles and abstracts. Among the remaining 11 potentially relevant studies, four were excluded due to endostatin administration via arterial infusion or discontinuation of endostatin in the first cycle during RT. Finally, seven studies [16, 18, 21-25] involving 271 patients were pooled for analysis.

\section{Included studies and patient characteristics}

The characteristics of the selected studies are summarized in Table 1. The included studies comprised three prospective cohort studies, three single-arm prospective studies and one single-arm retrospective study. Followup data were available for five studies, with a median follow-up period between 20.0 and 37.1 months. In total,
212 evaluable patients in four studies received endostatin combined with CCRT (ECRT) and 59 evaluable patients in three studies received endostatin combined with single RT (ERT). Patients received a total dose of 60-68 Gy in 30-34 fractions for 6-7 weeks. However, the methods of endostatin treatment differed among studies, including continuous intravenous pumping (CIV) of endostatin $\left(7.5 \mathrm{mg} / \mathrm{m}^{2} /\right.$ day $)$ over 5 days, administration of endostatin $\left(7.5 \mathrm{mg} / \mathrm{m}^{2} /\right.$ day $)$ over $4 \mathrm{~h}$ for 7 days at weeks $1,3,5$, and 7 or via an endostatin intravenous drip (IV) $(15 \mathrm{mg} /$ day) for 14 days per 3 weeks, etc. Almost all included patients had unresectable LA-NSCLC at the time of study entry. The median patient age ranged from 56 to 76 years.

\section{Pooled ORR and LCR}

Pooled ORR and LCR data are summarized in Table 2. The pooled overall ORR for the seven studies was $77.2 \%$ (95\% confidence interval $[\mathrm{CI}], 71.8-81.8 \% ; \mathrm{I}^{2}=0 \%$, Fig. 2a), $76.1 \%$ (95\% CI, 63.5-85.3\%; $\mathrm{I}^{2}=0 \%$, Fig. $\left.2 \mathrm{~b}\right)$ in the ERT group and $77.5 \%\left(95 \% \mathrm{CI}, 71.4-82.7 \%\right.$; $\mathrm{I}^{2}=0 \%$, Fig. 2c) in the ECRT group. Higher ORR was observed in the ERT group, compared with the RT alone group (76.1\% vs $61.7 \%$, respectively).

Only two studies in which the treatment regimens were ECRT and ERT reported LCR data. The pooled 1and 2-year LCR rates were $76.1 \%$ (95\% CI, 65.0-84.0\%; $\mathrm{I}^{2}=0 \%$, Fig. $2 \mathrm{~d}$ ) and $65.8 \%\left(95 \% \mathrm{CI}, 54.3-75.8 \% ; \mathrm{I}^{2}=0 \%\right.$, Fig. 2e), respectively.

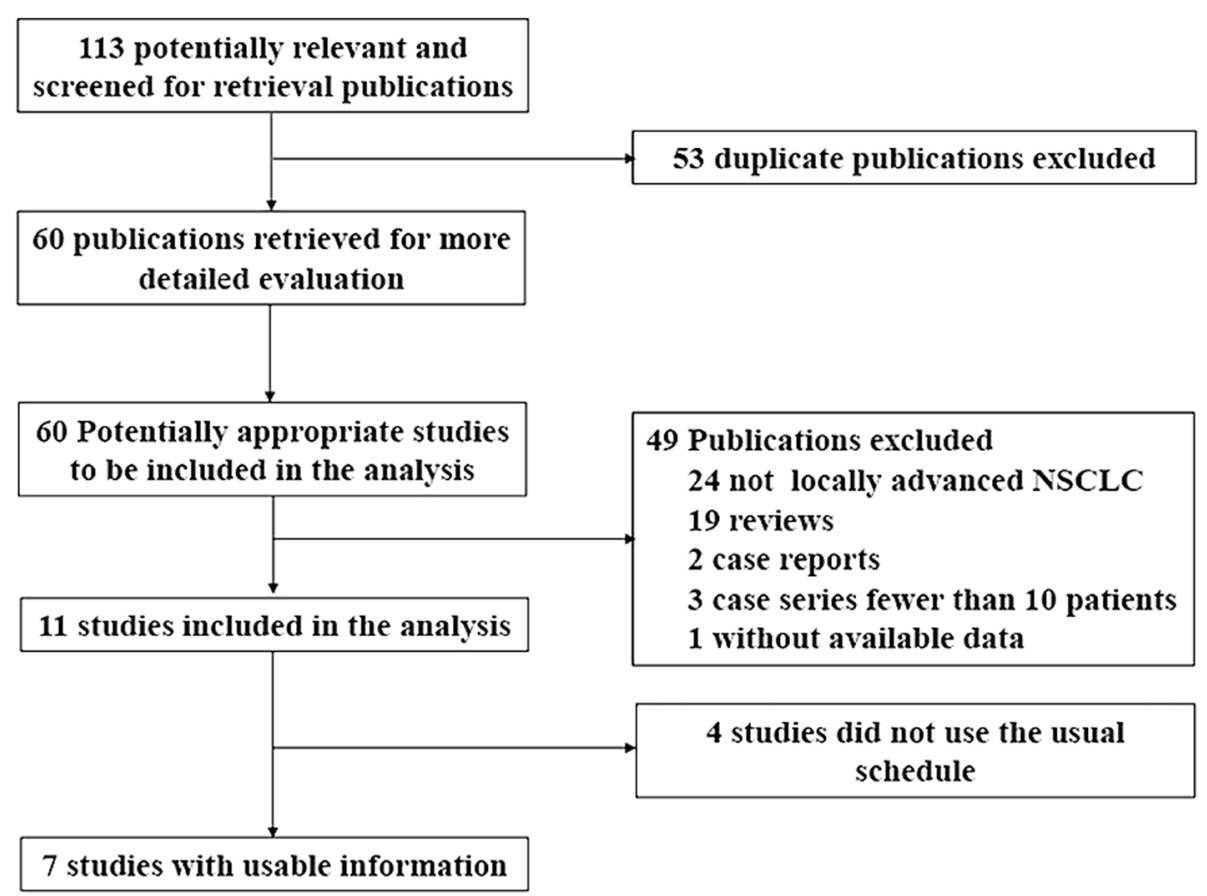

Fig. 1 Overview of study search and selection 
Table 1 Characteristics of the included studies

\begin{tabular}{|c|c|c|c|c|c|c|c|c|}
\hline Study & $\begin{array}{l}\text { Published } \\
\text { year }\end{array}$ & Study type & $\begin{array}{l}\text { No. of } \\
\text { cases }\end{array}$ & Endpoints & $\begin{array}{l}\text { Treatment } \\
\text { regimen }\end{array}$ & $\begin{array}{l}\text { Radiation } \\
\text { dose (Gy) }\end{array}$ & Endostatin usage & $\begin{array}{l}\text { Total duration of } \\
\text { endostatin }\end{array}$ \\
\hline Jiang [16] & 2012 & $\begin{array}{l}\text { Prospective } \\
\text { cohort study }\end{array}$ & 25 & $\begin{array}{l}\text { 1-, 2-yr OS rate, } \\
1-, 2-y r \text { LCR, OS, } \\
\text { ORR, AEs }\end{array}$ & ERT & 60 & $\begin{array}{l}15 \mathrm{mg} / \text { day IV for } 7 \text { days during the } \\
\text { first week of RT }\end{array}$ & 7 days $\times 1$ cycles \\
\hline Zhai [18] & 2019 & $\begin{array}{l}\text { Single-arm } \\
\text { prospective } \\
\text { study }\end{array}$ & 67 & $\begin{array}{l}1-, 2-, 3-y r \text { PFS/OS } \\
\text { rate, PFS,OS, } \\
\text { ORR, AES }\end{array}$ & ECRT & $60-66$ & $\begin{array}{l}7.5 \mathrm{mg} / \mathrm{m}^{2} / \text { day CIV for } 5 \text { days before } \\
\text { the beginning of RT, and then repeated } \\
\text { at week } 2,4 \text {, and } 6 \text { during RT }\end{array}$ & 5 days $\times 4$ cycles \\
\hline Sun [21] & 2016 & $\begin{array}{l}\text { Single-arm } \\
\text { prospective } \\
\text { study }\end{array}$ & 19 & ORR, PFS, OS, AES & ECRT & $60-66$ & $\begin{array}{l}7.5 \mathrm{mg} / \mathrm{m}^{2} / \text { day IV for } 14 \text { days per } \\
3 \text { weeks during RT }\end{array}$ & 14 days $\times 2$ cycles \\
\hline Bao [22] & 2015 & $\begin{array}{l}\text { Single-arm } \\
\text { prospective } \\
\text { study }\end{array}$ & 48 & $\begin{array}{l}\text { OS, 1-, 2-, 3-yr } \\
\text { PFS/OS rate and } \\
\text { LCR, PFS, ORR, AEs }\end{array}$ & ECRT & $60-66$ & $\begin{array}{l}7.5 \mathrm{mg} / \mathrm{m}^{2} / \text { day IV for } 7 \text { days before the } \\
\text { beginning of RT, and then repeated at } \\
\text { week } 2,4 \text {, and } 6 \text { during RT }\end{array}$ & 7 day $\times 4$ cycles \\
\hline Tang [23] & 2016 & $\begin{array}{l}\text { Single-arm } \\
\text { retrospective } \\
\text { study }\end{array}$ & 78 & PFS, OS, ORR & ECRT & $60-66$ & $\begin{array}{l}7.5 \mathrm{mg} / \mathrm{m}^{2} / \text { day IV over } 4 \mathrm{~h} \text { per day for } \\
7 \text { days, or CIV for } 5 \text { days, at week } 1,3,5 \\
\text { and } 7 \text {, endostatin administrated } \\
1 \text { week prior to CRT }\end{array}$ & $5 / 7$ days $\times 4$ cycles \\
\hline Wen [24] & 2009 & $\begin{array}{l}\text { Prospective } \\
\text { cohort study }\end{array}$ & 14 & $\begin{array}{l}\text { ORR, PFS, 1-yr } \\
\text { OS rate }\end{array}$ & ERT & $66-68$ & $\begin{array}{l}15 \mathrm{mg} / \text { day IV during the first three } \\
\text { weeks of RT }\end{array}$ & 21 days $\times 1$ cycles \\
\hline Chen [25] & 2017 & $\begin{array}{l}\text { Prospective } \\
\text { cohort study }\end{array}$ & 20 & ORR, PFS, OS, AES & ERT & $60-66$ & $\begin{array}{l}15 \mathrm{mg} / \text { day IV for } 14 \text { days per three } \\
\text { weeks during RT }\end{array}$ & 14 day $\times 2$ cycles \\
\hline
\end{tabular}

OS Overall survival, PFS Progression-free survival, ORR Objective response rate, $L C R$ Local control rate, $A E s$ Adverse events, ERT Endostatin combined with radiotherapy, ECRT Endostatin combined with concurrent chemoradiotherapy, yr Year, RT Radiotherapy, IV Intravenous injection, CIV Continuous

intravenous pumping

\section{Pooled survival}

The pooled survival data are summarized in Table 2. Only two studies in ECRT group reported PFS rates. The pooled 1-, 2- and 3-year PFS rates were 49.6\% (95\% CI, 40.5-58.6\%; I ${ }^{2}=0 \%$, Fig. 3a), 31.7\% (95\% CI, 23.8$40.8 \%$; $\mathrm{I}^{2}=0 \%$, Fig. $3 \mathrm{~b}$ ), and $23.7 \%$ (95\% CI, 16.7-32.5\%; $\mathrm{I}^{2}=56.3 \%$, Fig. 3c), respectively.

Four studies documented the 1-year OS rate, three the 2 -year OS rate, and two the 3-year OS rate. The overall pooled 1 - and 2-year OS rates were $79.4 \%$ (95\% CI, 72.1-85.1\%; $\mathrm{I}^{2}=25.2 \%$, Fig. $\left.4 \mathrm{a}\right)$ and $59.0 \%$ (95\% CI, 49.7-67.8\%; $\mathrm{I}^{2}=48.1 \%$, Fig. 4b), respectively. Based on stratification by treatment regimens, the pooled 1-, 2and 3-year OS rates in the ECRT group were $81.6 \%$ (95\% CI, 73.5-87.7\%; $\mathrm{I}^{2}=0 \%$, Fig. 4c), 55.7\% (95\% CI, $45.6-65.6 \%$; $\mathrm{I}^{2}=0 \%$, Fig. $4 \mathrm{~d}$ ) and $43.9 \%$ (95\% CI, $29.8-$ $59.0 \% ; \mathrm{I}^{2}=0 \%$, Fig. $4 \mathrm{e}$ ); the pooled 1 -year OS rate in the ERT group was $72.8 \%$ (95\% CI, 55.9-85.0\%; $\mathrm{I}^{2}=63.3 \%$ ).

Six of the included studies had recorded median PFS values. Patients received ECRT in four of these studies and ERT in the remaining two studies, with only three of the above studies recording both the PFS value and 95\% CI. Accordingly, pooled median PFS was calculated by a weighted average of the single study median [26]. The pooled median PFS was recorded as 11.3 months overall, 11.2 months in the ECRT group, and 11.8 months in the ERT group.

OS data and 95\% CI were reported in four studies. The overall pooled median OS was 18.9 months (95\% CI, 15.3-22.5, $\mathrm{I}^{2}=87.6 \%$ ), 18.4 months (95\% CI, 9.7-
27.0, $\left.\mathrm{I}^{2}=92.6 \%\right)$ in the ECRT group and 19.6 months (95\% CI, 16.2-23.1, $\left.\mathrm{I}^{2}=78.7 \%\right)$ in the ERT group.

\section{Safety}

The most common AEs documented in the five selected studies, including 179 patients, were radiation pneumonitis, radiation esophagitis, thrombocytopenia, and anemia. Additionally, nausea/vomiting, neutropenia and leukopenia were three commonly observed AEs in three of the above four studies. Pooled data on AEs are summarized in Table 3.

\section{Radiation pneumonitis and esophagitis}

The pooled frequencies of any grade and grade $\geq 3$ radiation pneumonitis were 55.9 and $10.9 \%$ overall, 50.7 and $11.9 \%$ in the ECRT group, and 64.1 and $9.4 \%$ in the ERT group, respectively. The pooled frequencies of any grade and grade $\geq 3$ radiation esophagitis were 77.4 and $11.6 \%$ overall, 89.7 and $12.2 \%$ in the ECRT group, and 55.5 and $9.4 \%$ in the ERT group, respectively.

\section{Hematological toxicity}

More than $10 \%$ of grade $\geq 3$ hematological toxicities in all patients were neutropenia, leukopenia, and anemia, with incidences of $27.8,35.5$, and $10.5 \%$, respectively. The pooled rates were $40.1 \%$ vs $2.1,43.4 \%$ vs 0 , and $12.3 \%$ vs $2.1 \%$, respectively, in the ECRT and ERT groups. Rates of thrombocytopenia of grade $\geq 3$ were 6.9 , 10.1 and $2.1 \%$ for all patients, ECRT and ERT groups, respectively. 
Table 2 Pooled efficacy of endostatin combined with radiotherapy or chemoradiotherapy

\begin{tabular}{|c|c|c|c|c|}
\hline Endpoints & Group & No. of studies & No. of cases & Weighted pooled data (95\%Cl) \\
\hline \multicolumn{5}{|l|}{ Response rate } \\
\hline \multirow[t]{3}{*}{ ORR (\%) } & Overall & 7 & 271 & $77.2(71.8-81.8)$ \\
\hline & ECRT & 4 & 212 & $77.5(71.4-82.7)$ \\
\hline & ERT & 3 & 59 & $76.1(63.5-85.3)$ \\
\hline 1-yr LCR (\%) & Overall & 2 & 73 & $76.1(65.0-84.0)$ \\
\hline 2-yr LCR (\%) & Overall & 2 & 73 & $65.8(54.3-75.8)$ \\
\hline \multicolumn{5}{|c|}{ Progression-free survival } \\
\hline \multirow[t]{3}{*}{ Median PFS (months) } & Overall & 6 & 246 & 11.3 \\
\hline & ECRT & 4 & 212 & 11.2 \\
\hline & ERT & 2 & 34 & 11.8 \\
\hline 1-yr PFS rate (\%) & ECRT & 2 & 115 & $49.6(40.5-58.6)$ \\
\hline 2-yr PFS rate (\%) & ECRT & 2 & 115 & $31.7(23.8-40.8)$ \\
\hline 3-yr PFS rate (\%) & ECRT & 2 & 115 & $23.7(16.7-32.5)$ \\
\hline \multicolumn{5}{|l|}{ Overall survival } \\
\hline \multirow[t]{3}{*}{ Median OS (months) } & Overall & 4 & 142 & $18.9(15.3-22.5)$ \\
\hline & ECRT & 2 & 97 & $18.4(9.7-27.0)$ \\
\hline & ERT & 2 & 45 & $19.6(16.2-23.1)$ \\
\hline \multirow[t]{3}{*}{ 1-yr OS rate (\%) } & Overall & 4 & 154 & $79.4(72.1-85.1)$ \\
\hline & ECRT & 2 & 115 & $81.6(73.5-87.7)$ \\
\hline & ERT & 2 & 39 & $72.8(55.9-85.0)$ \\
\hline $2-y r$ OS rate (\%) & Overall & 3 & 140 & $59.0(49.7-67.8)$ \\
\hline \multirow[t]{2}{*}{ 3-yr OS rate (\%) } & ECRT & 2 & 115 & $55.7(45.6-65.6)$ \\
\hline & ECRT & 2 & 115 & $43.9(29.8-59.0)$ \\
\hline
\end{tabular}

OS Overall survival, PFS Progression-free survival, ORR Objective response rate, LCR Local control rate, ERT Endostatin combined with radiotherapy, ECRT Endostatin combined with concurrent chemoradiotherapy, yr Year

\section{Other toxicities}

Several other toxicities, including nausea, arrhythmia, fatigue, hemorrhage, and hypertension were additionally reported (Table 3). All of above AEs incidences of grade $\geq 3$ were less than $10 \%$ for either all patients or for any of subgroups. Only one study reported $\mathrm{AE}$ of hypertension, in which patients received ECRT, with a frequency of $2 \%$ in any grade, and $0 \%$ in grade $\geq 3$, respectively.

\section{Publication bias and sensitivity analysis}

Publication bias was assessed for ORR according to Begg's test and no significant publication bias was observed (Fig. 5). Besides, results of sensitivity analysis by omitting one study at a time did not substantially change the overall results.

\section{Discussion}

CRT plus consolidation durvalumab is now considered standard of care for inoperable stage III NSCLC, but the optimal treatment strategies for the sequence and combination of CRT, immunotherapy, and even anti- angiogenic therapy are still being studied. Although data from prospective phase III randomized control studies evaluating the efficacy and safety of endostatin combined with RT or CCRT for patients with LA-NSCLC are lacking, our pooled analysis indicates that endostatin combined with CCRT or RT presents a promising treatment modality in treatment of LA-NSCLC; subgroups of ECRT and ERT have similar efficacy and survival benefit, but patients in the ERT subgroup had lower rates of toxicity.

Since tumor angiogenesis has been identified as a critical step in growth and metastasis of malignant solid tumors, anti-angiogenesis strategies have become established as an effective therapeutic approach [27-29]. Vascular endothelial growth factor (VEGF), a specific and potent angiogenic factor, contributes to the development of solid tumors by promoting angiogenesis. Several anti-VEGF or anti-VEGF-receptor (VEGFR) strategies have been developed to date, including neutralizing antibodies to VEGF/VEGFR, soluble VEGFR/VEGFR hybrids, and receptor tyrosine kinase inhibitors [30-32]. Chemotherapy combined with anti-angiogenic drugs 


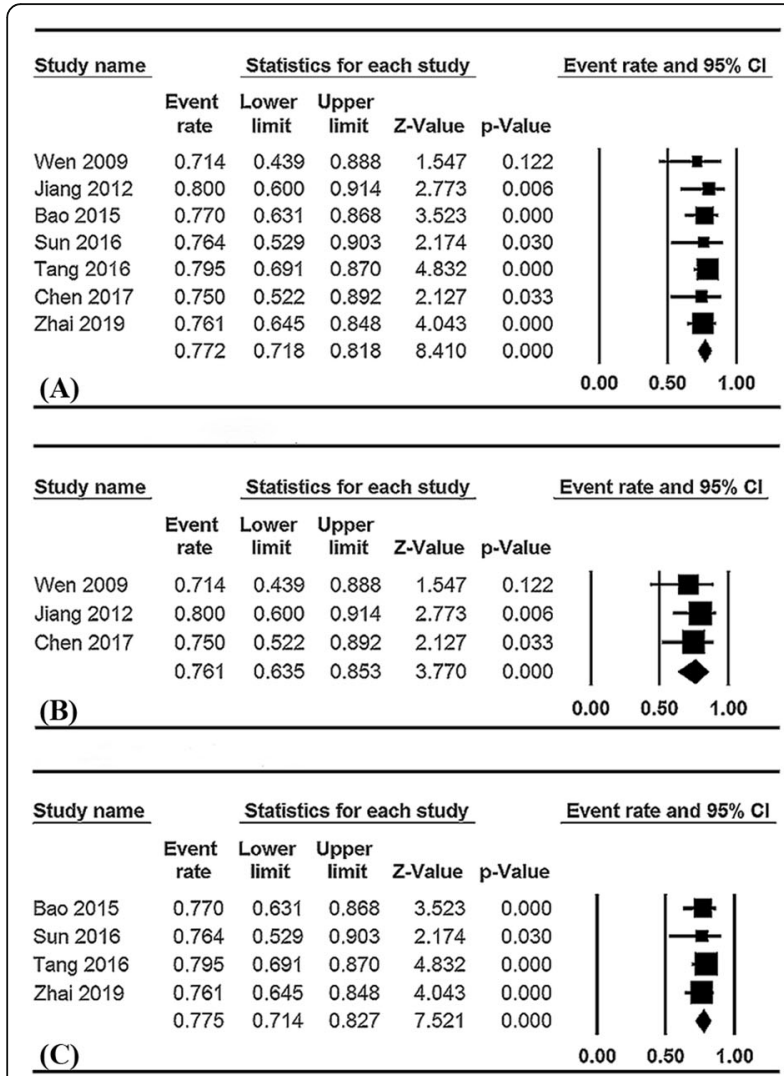

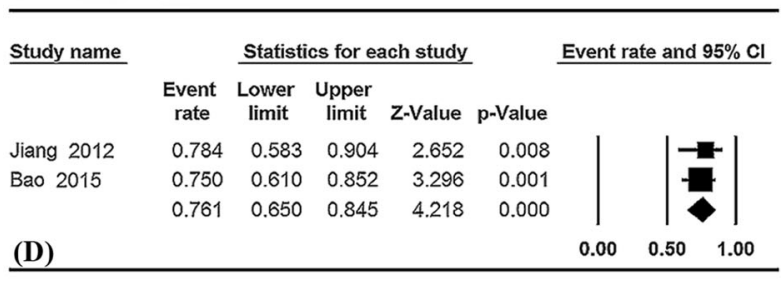

Fig. 2 Pooled ORR for all patients (a), ERT (b) and ECRT (c) groups; pooled LCR for all patients, 1-year LCR (d) and 2-year LCR (e). ORR: objective response rates; ERT: endostatin combined with radiotherapy alone; ECRT: endostatin combined with concurrent chemoradiotherapy; LCR: local control rates

[33-35], including bevacizumab (a VEGF-A monoclonal antibody), recombinant human endostatin, and ramucirumab (a VEGFR monoclonal antibody), has led to significantly prolonged survival, compared with chemotherapy alone, and is currently approved by the U.S. Food and Drug Administration (FDA) and/or China FDA for first- or second-line treatment of advanced NSCLC.

Solid tumors generally have characteristics of hypoxia and exhibit resistance to radiation to some extent, leading to failure of local control. Therefore, attempts to increase the sensitivity of RT via tumor oxygen enrichment present a novel direction for research [36, 37]. One of the most common factors causing hypoxia is inadequate vascular supply of the tumor, and thus sufficient blood vessel supply in the tumor microenvironment may be essential to improve the tumor radiation response for patients treated via RT [38]. Recombinant human endostatin is an endogenous broad-spectrum angiogenesis inhibitor produced by proteolytic cleavage of collagen XVIII that is suggested to interfere with the pro-angiogenic action of growth factors, such as basic fibroblast growth factor and VEGF. Preclinical studies have shown that recombinant human endostatin could transiently "normalize" the tumor vasculature to enhance efficiency of oxygen delivery and sensitivity to radiation treatment $[39,40]$. Our pooled data indicate that combination of endostatin and RT with or without chemotherapy leads to better response rate, local control rate, and survival, demonstrating superior short- and long-term survival benefits, which are not inferior to the results of previous randomized controlled trials (RCTs) of CCRT (summarized in Table 4) [5, 41-44].

Although RTOG 0617 trial showed a superior median OS of 28.7 months, $69 \%$ patients in this study had stage IIIA disease [41]. In contrast, more than 50\% patients in our pooled analysis had stage IIIB disease, which may be one of the factors contributing to survival differences. In a phase II trial involving $83 \%$ unresectable stage IIIB patients, endostatin combined with CCRT resulted in a median OS of 24 months [22]. In each of the RCTs listed in Table 4 , over $50 \%$ of patients had a performance status (PS) score of 0 ; however, in our pooled analysis, only $28.5 \%$ of patients had a PS score of 0 . In a phase II trial involving only $13.4 \%$ of patients with a PS score of 0 , endostatin combined with CCRT resulted in median PFS and OS of 13.3 months and 34.7 months, respectively [18]. 


\begin{tabular}{|c|c|c|c|c|c|c|c|c|}
\hline \multirow[t]{2}{*}{ Study name } & \multicolumn{5}{|c|}{ Statistics for each study } & \multicolumn{3}{|c|}{ Event rate and $95 \% \mathrm{Cl}$} \\
\hline & $\begin{array}{c}\text { Event } \\
\text { rate }\end{array}$ & $\begin{array}{l}\text { Lower } \\
\text { limit }\end{array}$ & $\begin{array}{c}\text { Upper } \\
\text { limit }\end{array}$ & Z-Value & p-Value & & & \\
\hline Bao 2015 & 0.480 & 0.344 & 0.619 & -0.277 & 0.782 & & & \\
\hline \multirow[t]{2}{*}{ Zhai 2019} & 0.507 & 0.389 & 0.624 & 0.115 & 0.909 & & & \\
\hline & 0.496 & 0.405 & 0.586 & -0.091 & 0.927 & & & \\
\hline (A) & & & & & & 0.00 & 0.50 & 1.00 \\
\hline
\end{tabular}

\begin{tabular}{|c|c|c|c|c|c|c|c|}
\hline \multirow[t]{2}{*}{ Study name } & \multicolumn{4}{|c|}{ Statistics for each study } & \multicolumn{3}{|c|}{ Event rate and $95 \% \mathrm{Cl}$} \\
\hline & $\begin{array}{c}\text { Event } \\
\text { rate }\end{array}$ & $\begin{array}{l}\text { Lower } \\
\text { limit }\end{array}$ & $\begin{array}{c}\text { Upper } \\
\text { limit }\end{array}$ & Z-Value & $p$-Value & & \\
\hline Bao 2015 & 0.270 & 0.164 & 0.412 & -3.059 & 0.002 & & \\
\hline \multirow[t]{2}{*}{ Zhai 2019} & 0.348 & 0.244 & 0.469 & -2.448 & 0.014 & & \\
\hline & 0.317 & 0.238 & 0.408 & -3.817 & 0.000 & & \\
\hline (B) & & & & & & 0.50 & 1.00 \\
\hline
\end{tabular}

\begin{tabular}{|c|c|c|c|c|c|c|c|}
\hline \multirow[t]{2}{*}{ Study name } & \multicolumn{5}{|c|}{ Statistics for each study } & \multicolumn{2}{|c|}{ Event rate and $95 \% \mathrm{Cl}$} \\
\hline & $\begin{array}{c}\text { Event } \\
\text { rate }\end{array}$ & $\begin{array}{c}\text { Lower } \\
\text { limit }\end{array}$ & $\begin{array}{c}\text { Upper } \\
\text { limit }\end{array}$ & Z-Value & $p$-Value & & \\
\hline Bao 2015 & 0.160 & 0.081 & 0.292 & -4.212 & 0.000 & & \\
\hline Zhai 2019 & 0.282 & 0.187 & 0.401 & -3.442 & 0.001 & & \\
\hline & 0.237 & 0.167 & 0.325 & -5.225 & 0.000 & & \\
\hline (C) & & & & & & 0.00 & 1.00 \\
\hline
\end{tabular}

Fig. 3 Pooled PFS rates for ECRT group, 1-year (a), 2-year (b), and 3-year PFS rates (c). PFS: progression-free survival; ECRT: endostatin combined with concurrent chemoradiotherapy

Recently, the PACIFIC study conducted in patients with unresectable stage III NSCLC showed a significant survival advantage with durvalumab consolidation therapy after CCRT [8], achieving a 3 -year OS rate of $57 \%$ in the durvalumab group versus $43.5 \%$ in the control group. Based on this study, National Comprehensive Cancer Network guidelines have recommended this regimen as standard treatment for unresectable stage III NSCLC [45]. However, the optimal sequence and combination of CRT/RT and immunotherapy are being studied. Results from several phase II trials, such as the DETERRED and ETOP NICOLAS studies, have indicated that concurrent CRT with checkpoint inhibitors (ICIs) (atezolizumab/nivolumab) for the treatment of advanced NSCLC might be feasible and has no significant added toxicities over historical rates [46, 47]. Currently, many ongoing phase II/III clinical trials, such as PACI FIC2 (NCT03519971), KEYNOTE-799 (NCT03631784), EA5181 (NCT04092283), CheckMate73L (NCT04026 412), etc., are evaluating the optimal treatment strategies of immunotherapy-radiotherapy combinations.

Although CCRT plays an indispensable role in the treatment of unresectable stage III NSCLC, some patients, especially the elderly or those with poor performance status who cannot tolerate toxicity induced by chemotherapy, have to receive sequential CRT or even RT alone [4, 5, 48]. Our pooled analysis indicated that patients treated with endostatin in combination with RT alone have comparable PFS (11.8 vs 11.2 months), OS (19.6 vs18.4 months), and ORR (76.1\% vs $77.5 \%)$ to those administered endostatin with CCRT. In addition, pooled ORR data from the three prospective cohort studies 


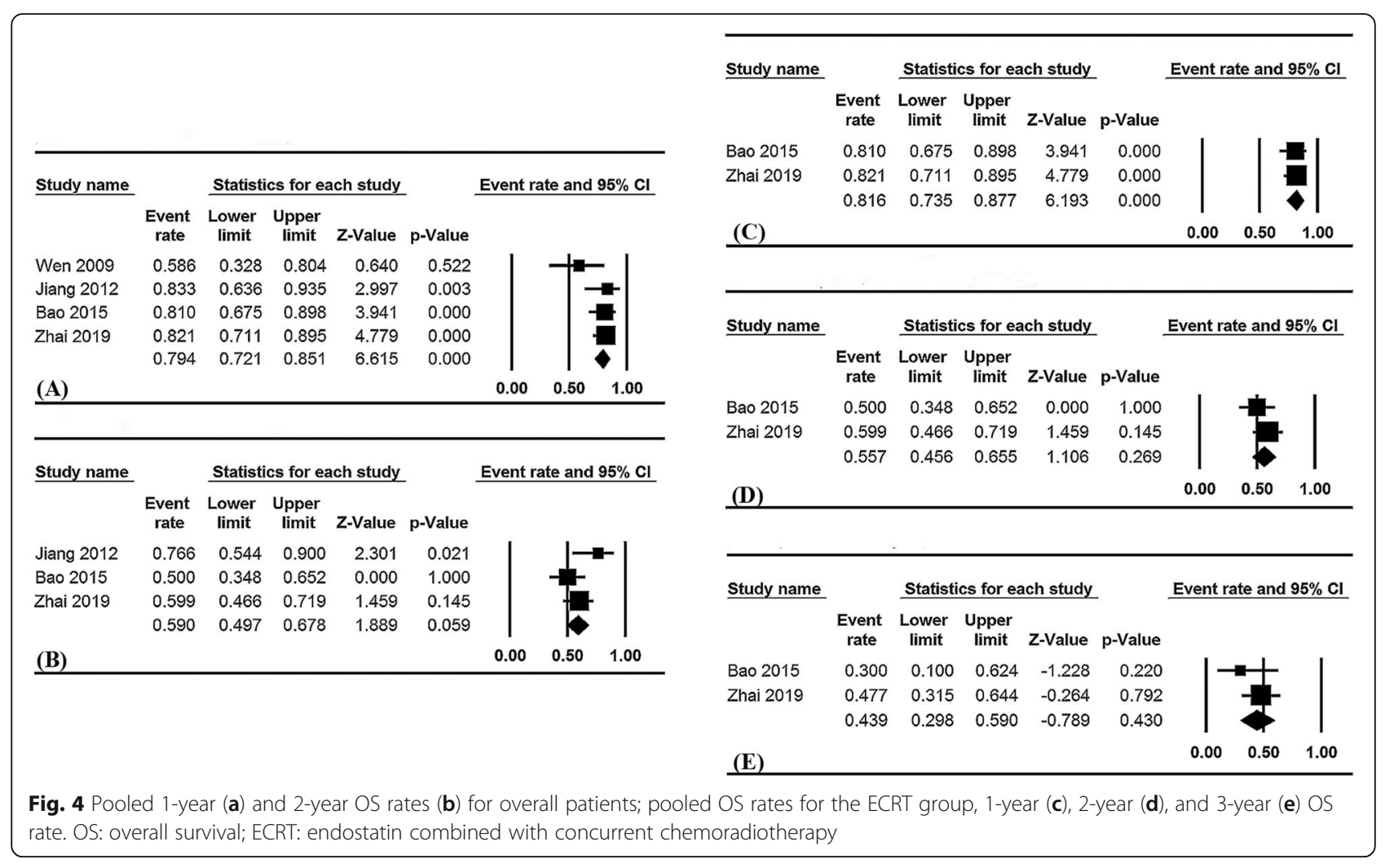

showed that patients subjected to endostatin combined with RT had higher ORR (76.1\% vs $61.7 \%)$, compared with the RT alone patient group. Therefore, combination therapy of RT and endostatin may be a promising strategy for LA-NSCLC patients with poor PS who cannot tolerate chemotherapy.

Of note, the duration and intervals of endostatin and radiotherapy combinations differed in clinical trials and may affect the outcomes (as shown in Table 1). Results from preclinical studies showed that endostatin treatment could transiently normalize the tumor vasculature by reducing microvessel density and increasing pericytic coverage of the vessel endothelium, thereby providing a time window (about 1 week) to enhance the sensitivity to RT; thus, RT delivery in this period resulted in maximal anti-tumor outcomes $[15,49]$. CT perfusion imaging and hypoxia imaging suggested that the "time window" was within about 1 week after administration, during which endostatin improved blood perfusion and decreased hypoxia of lung cancer [14]. These studies provide an important experimental basis for combining endostatin with radiotherapy within the time window of 7 days (range, 5-10) after endostatin administration. In addition, given the short half-life of endostatin in vivo, CIV is considered a better delivery route to maintain a steady concentration and may improve its efficacy [4951]. A recent study [52] which compared the outcomes of two phase II trials that involved different administration routes of endostatin combined with CCRT showed that endostatin at $7.5 \mathrm{mg} / \mathrm{m}^{2} / 24 \mathrm{~h}$ CIV for 5 days achieved higher 3 - and 5-year OS rates (50.3, 41\%) and safety than endostatin at $7.5 \mathrm{mg} / \mathrm{m}^{2} /$ day IV for 7 days. Therefore, administration of $7.5 \mathrm{mg} / \mathrm{m}^{2} / 24 \mathrm{~h}$ CIV for 5 days per 2 weeks, from 1 week pre-RT to the end of RT, could be a preferred scheme, on the basis of the current studies. However, the optimal duration and intervals of endostatin administration require further investigation.

In our pooled analysis, we observed that grade $\geq 3$ AEs in the ECRT group were similar to those caused by CCRT reported previously (summarized in Table 5), indicating that addition of endostatin to CCRT did not obviously increase the main AEs. The pooled incidences of grade $\geq 3$ radiation pneumonitis and radiation esophagitis were 10.9 and $11.6 \%$, respectively, analogous to previous findings. Importantly, compared with the ECRT group, significantly lower rates of grade $\geq 3$ AEs were observed in the ERT group, such as radiation pneumonitis (9.4\% vs $11.9 \%)$, radiation esophagitis $(9.4 \%$ vs $12.2 \%)$, nausea/vomiting ( $0 \%$ vs $6.3 \%$ ), thrombocytopenia $(2.1 \%$ vs $10.1 \%)$, neutropenia ( $2.1 \%$ vs $40.1 \%)$, anemia ( $2.1 \%$ vs $12.3 \%$ ), and leukopenia (0\% vs $43.4 \%$ ).

Our pooled analysis has several limitations. Firstly, four in seven included studies belonged to single-arm trial and lacked a comparative control group, and 
Table 3 Pooled adverse events of endostatin combined with radiotherapy or chemoradiotherapy

\begin{tabular}{|c|c|c|c|c|}
\hline \multirow[t]{2}{*}{ Events } & \multirow[t]{2}{*}{ Grade } & \multicolumn{3}{|c|}{ Incidence, \% (95\% Cl) } \\
\hline & & Overall & ECRT group & ERT group \\
\hline \multirow[t]{2}{*}{ Radiation pneumonitis } & All & $55.9(31.4-77.9)$ & $50.7(20.9-80.0)$ & $64.1(27.3-89.4)$ \\
\hline & $\geq 3$ & $10.9(5.4-20.8)$ & $11.9(4.5-27.9)$ & $9.4(3.3-24.0)$ \\
\hline \multirow[t]{2}{*}{ Radiation esophagitis } & All & $77.4(69.4-83.7)$ & 89.7 (83.1-93.9) & $55.5(40.9-69.3)$ \\
\hline & $\geq 3$ & $11.6(7.6-17.5)$ & $12.2(7.6-19.0)$ & $9.4(3.3-24.0)$ \\
\hline \multirow[t]{2}{*}{ Neutropenia } & All & $76.5(55.6-89.4)$ & 85.7 (78.5-90.7) & $25.1(71.6-89.9)$ \\
\hline & $\geq 3$ & $27.8(14.3-47.0)$ & $40.1(30.3-50.8)$ & $2.1(0.3-13.7)$ \\
\hline \multirow[t]{2}{*}{ Leukopenia } & All & 84.5 (49.7-96.8) & 91.8 (78.2-97.2) & 40 \\
\hline & $\geq 3$ & $35.5(18.5-57.7)$ & $43.4(27.2-61.2)$ & 0 \\
\hline \multirow[t]{2}{*}{ Anemia } & All & $54.7(34.7-73.3)$ & $70.5(62.1-77.6)$ & $28.9(17.6-43.6)$ \\
\hline & $\geq 3$ & $10.5(6.2-17.2)$ & $12.3(7.6-19.1)$ & $2.1(0.3-13.7)$ \\
\hline \multirow[t]{2}{*}{ Thrombocytopenia } & All & $46.0(23.2-59.3)$ & $52.5(34.2-70.2)$ & $35.7(23.1-50.7)$ \\
\hline & $\geq 3$ & $6.9(2.4-18.3)$ & $10.1(3.3-26.7)$ & $2.1(0.3-13.7)$ \\
\hline \multirow[t]{2}{*}{ Nausea/vomiting } & All & $48.2(32.5-64.2)$ & $54.1(38.7-68.7)$ & 40 \\
\hline & $\geq 3$ & $5.8(2.8-11.6)$ & $6.3(3.0-12.9)$ & 0 \\
\hline \multirow[t]{2}{*}{ Arrhythmia } & All & $25.7(9.5-52.7)$ & 37 & 15 \\
\hline & $\geq 3$ & 0 & 0 & 0 \\
\hline \multirow[t]{2}{*}{ Fatigue } & All & $58.0(39.3-74.7)$ & $67.4(56.7-76.5)$ & 40 \\
\hline & $\geq 3$ & $2.6(0.7-8.7)$ & $2.7(0.7-1.3)$ & 0 \\
\hline \multirow[t]{2}{*}{ Hemorrhage } & All & NR & $15.2(9.0-24.5)$ & NR \\
\hline & $\geq 3$ & $N R$ & $1.8(0.4-8.3)$ & $N R$ \\
\hline \multirow[t]{2}{*}{ Hypertension } & All & NR & 2 & $N R$ \\
\hline & $\geq 3$ & NR & 0 & NR \\
\hline
\end{tabular}

ERT Endostatin combined with radiotherapy, ECRT Endostatin combined with concurrent chemoradiotherapy, NR Not reported

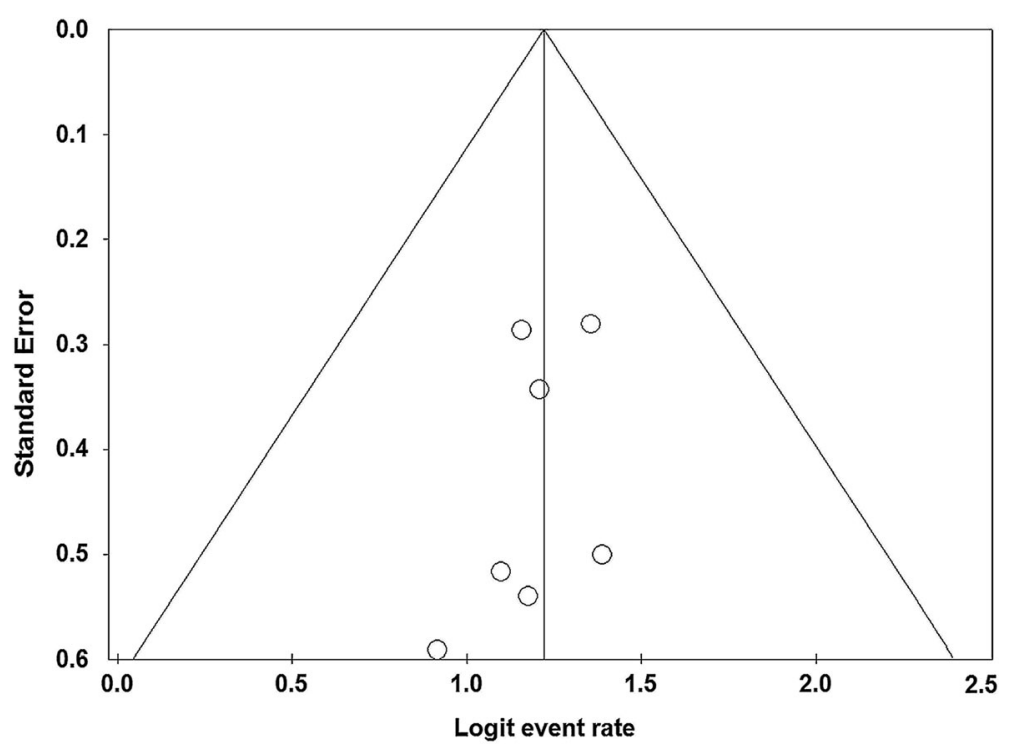

Fig. 5 Funnel plot of publication bias for ORR. ORR: objective response rates 
Table 4 The efficacy of concurrent chemoradiotherapy in previously reported phase II/III randomized controlled trials

\begin{tabular}{|c|c|c|c|c|c|c|c|c|c|c|c|c|}
\hline \multirow[t]{2}{*}{ Study } & \multirow[t]{2}{*}{ Number } & \multirow[t]{2}{*}{ CRT regimen } & \multirow{2}{*}{$\begin{array}{l}\text { mPFS } \\
\text { (months) }\end{array}$} & \multicolumn{2}{|c|}{ PFS rate (\%) } & \multirow{2}{*}{$\begin{array}{l}\text { mOS } \\
\text { (months) }\end{array}$} & \multicolumn{2}{|c|}{ OS rate (\%) } & \multirow{2}{*}{$\begin{array}{l}\text { ORR } \\
(\%)\end{array}$} & \multicolumn{3}{|c|}{ LCR (\%) } \\
\hline & & & & $1-y r$ & $2-y r$ & & $1-y r$ & $2-y r$ & & $1-y r$ & $2-y r$ & Overall \\
\hline \multirow[t]{2}{*}{ RTOG 9410 [5] } & 195 & $R T+V P$ & NR & NR & NR & 17 & 61.5 & 37.4 & 70.0 & NR & NR & 70 \\
\hline & 187 & $R T+E P$ & NR & NR & NR & 15.6 & 60.9 & 31.6 & 65.0 & NR & $N R$ & 71 \\
\hline \multirow[t]{4}{*}{ RTOG 0617 [41] } & 151 & $L D R+P C$ & 11.8 & 49.2 & 29.1 & 28.7 & 80.0 & 57.6 & NR & 83.7 & 69.3 & $N R$ \\
\hline & 107 & $\mathrm{HDR}+\mathrm{PC}$ & 9.8 & 41.2 & 21.4 & 20.3 & 69.8 & 44.6 & NR & 75.2 & 61.4 & $N R$ \\
\hline & 137 & $\mathrm{LDR}+\mathrm{PC}+\mathrm{Cet}$ & 10.8 & 44.3 & 24.2 & 25 & 76.2 & 56.3 & NR & 77.8 & 61.8 & NR \\
\hline & 100 & $\mathrm{HDR}+\mathrm{PC}+\mathrm{Cet}$ & 10.7 & 46.3 & 27.5 & 24 & 71.1 & 50.1 & NR & 82.4 & 69.3 & $N R$ \\
\hline \multirow[t]{2}{*}{ PROCLAIM [42] } & 283 & $\mathrm{RT}+\mathrm{PP}$ & 14.1 & NR & NR & 26.8 & 76.0 & 52.0 & 35.9 & NR & NR & 62.7 \\
\hline & 272 & $R T+E P$ & 9.8 & NR & NR & 25 & 77.0 & 52.0 & 33.0 & NR & $N R$ & 54.2 \\
\hline \multirow[t]{2}{*}{ CAMS [43] } & 95 & $R T+E P$ & 14 & 56.8 & 29.5 & 23.3 & 74.1 & 48.4 & 73.7 & NR & $N R$ & NR \\
\hline & 96 & $R T+P C$ & 12 & 50 & 17.7 & 20.7 & 80.2 & 43.8 & 64.6 & NR & NR & NR \\
\hline \multirow[t]{2}{*}{ WJOG5008L [44] } & 54 & $\mathrm{RT}+\mathrm{SP}$ & 14.8 & 55.6 & 29.6 & 40.9 & 87.0 & 75.6 & 76.9 & NR & 51 & NR \\
\hline & 54 & $\mathrm{RT}+\mathrm{VP}$ & 12.3 & 53.7 & 18.5 & 39 & 87.0 & 68.5 & 80.8 & NR & 28 & $N R$ \\
\hline
\end{tabular}

$C R T$ Chemoradiotherapy, $R T$ Radiotherapy, LDR Low dose radiation, HDR High dose radiation, VP Vinblastine plus cisplatin, EP Etoposide plus cisplatin, $P C$ Paclitaxel plus carboplatin, Cet Cetuximab, PP Pemetrexed plus cisplatin, SP S1 plus cisplatin, NR Not reported, PFS Progression-free survival, $m P F S$ Median progression-free survival, OS Overall survival, mOS Median overall survival, ORR Objective response rate, LCR Local control rate, yr Year

another three of the studies were prospective cohort trials with a comparative control group, they were of nonrandom design and lacked sufficient data to facilitate effective analysis, Secondly, heterogeneity of the dose regimen or endostatin usage between studies was not taken into consideration, resulting in unstable merged findings. Thirdly, the current results suggest that endostatin combined with RT alone is comparable to endostatin with CCRT in terms of ORR, LCR, and survival. However, the differences in efficacy and safety between the two treatment methods remain to be established. Further well-designed prospective randomized controlled clinical trials are warranted to reach definitive conclusions.

Increasing interest has emerged in studying the feasibility of combined radiotherapy, antiangiogenic agents and ICIs. Current evidence suggests that antiangiogenic agents have the potential for increasing the response to immunotherapy by modulating the tumor microenvironment (TME) [53]. The IMpower150 study identified the synergic effect of antiangiogenic agents plus immunotherapy [54], in which patients in the atezolizumab plus bevacizumab and paclitaxel/carboplatin $(\mathrm{ABCP})$ group achieved survival advantage over those in the bevacizumab plus paclitaxel/carboplatin (BCP) group. Similarly,

Table 5 Adverse events of concurrent chemoradiotherapy in previously reported phase II/III randomized controlled trials

\begin{tabular}{|c|c|c|c|c|c|c|c|c|c|c|c|c|c|}
\hline \multirow[t]{2}{*}{ Study } & \multirow[t]{2}{*}{ CRT regimen } & \multicolumn{2}{|c|}{$\begin{array}{l}\text { Leukopenia } \\
(\%)\end{array}$} & \multicolumn{2}{|c|}{$\begin{array}{l}\text { Neutropenia } \\
(\%)\end{array}$} & \multicolumn{2}{|c|}{$\begin{array}{l}\text { Thrombocytopenia } \\
(\%)\end{array}$} & \multicolumn{2}{|c|}{$\begin{array}{l}\text { Anemia } \\
(\%)\end{array}$} & \multicolumn{2}{|c|}{$\begin{array}{l}\text { Radiation } \\
\text { pneumonitis (\%) }\end{array}$} & \multicolumn{2}{|c|}{$\begin{array}{l}\text { Radiation } \\
\text { esophagitis (\%) }\end{array}$} \\
\hline & & All & $\geq 3$ & All & $\geq 3$ & All & $\geq 3$ & All & $\geq 3$ & All & $\geq 3$ & All & $\geq 3$ \\
\hline \multirow[t]{2}{*}{ RTOG 9410 [5] } & $R T+V P$ & NR & 83.9 & NR & NR & NR & 9.3 & NR & 11.8 & NR & 12.5 & $N R$ & 22.2 \\
\hline & $R T+E P$ & NR & 68.4 & NR & NR & NR & 16.0 & NR & 18.8 & NR & 16.9 & $N R$ & 44.9 \\
\hline \multirow[t]{4}{*}{ RTOG 0617 [41] } & $L D R+P C$ & 61.1 & 32.1 & 40.4 & 23.8 & 37.7 & 6.6 & 58.9 & 7.9 & 10.0 & 4.6 & 46.4 & 7.3 \\
\hline & $H D R+P C$ & 57.0 & 30.8 & 46.7 & 26.2 & 41.1 & 7.5 & 58.9 & 8.0 & 12.1 & 1.0 & 54.2 & 15.0 \\
\hline & $\mathrm{LDR}+\mathrm{PC}+\mathrm{Cet}$ & 51.8 & 30.7 & 54.7 & 40.9 & 35.8 & 8.0 & 63.4 & 11.6 & 12.4 & 7.3 & 43.8 & 6.6 \\
\hline & $\mathrm{HDR}+\mathrm{PC}+\mathrm{Cet}$ & 54.0 & 37.0 & 59.0 & 46.9 & 44.0 & 16.0 & 51.0 & 6.0 & 17.0 & 6.0 & 54.0 & 19.0 \\
\hline \multirow[t]{2}{*}{ PROCLAIM [42] } & $R T+P P$ & 36.7 & 22.6 & 42.8 & 24.4 & 55.0 & 40.3 & 40.3 & 8.8 & 17.0 & 1.8 & 48.1 & 15.5 \\
\hline & $\mathrm{RT}+\mathrm{EP}$ & 40.8 & 30.1 & 54.8 & 44.5 & 85.0 & 29.0 & 45.6 & 13.6 & 10.7 & 2.6 & 50.7 & 20.6 \\
\hline CAMS [43] & $\begin{array}{l}R T+E P \\
R T+P C\end{array}$ & $\begin{array}{l}95.8 \\
92.7\end{array}$ & $\begin{array}{l}30.5 \\
20.7\end{array}$ & $\begin{array}{l}N R \\
N R\end{array}$ & $\begin{array}{l}\text { NR } \\
N R\end{array}$ & $\begin{array}{l}12.7 \\
5.2\end{array}$ & $\begin{array}{l}0 \\
0\end{array}$ & $\begin{array}{l}24.2 \\
13.5\end{array}$ & $\begin{array}{l}0 \\
0\end{array}$ & $\begin{array}{l}76.8 \\
72.9\end{array}$ & $\begin{array}{l}7.4 \\
8.3\end{array}$ & $\begin{array}{l}87.0 \\
84.0\end{array}$ & $\begin{array}{l}20.0 \\
6.3\end{array}$ \\
\hline \multirow[t]{2}{*}{ WJOG5008L [44] } & $\mathrm{RT}+\mathrm{SP}$ & 96.3 & 40.7 & 88.9 & 33.3 & 42.6 & 9.3 & 79.6 & 25.5 & 24.1 & 9.3 & 66.7 & 3.7 \\
\hline & $R T+V P$ & 100 & 79.6 & 94.4 & 75.9 & 22.0 & 3.7 & 88.9 & 27.8 & 20.4 & 7.4 & 74.1 & 0.0 \\
\hline
\end{tabular}

CRT Chemoradiotherapy, RT Radiotherapy, LDR Low dose radiation, HDR High dose radiation, VP Vinblastine plus cisplatin, EP Etoposide plus cisplatin, $P C$ Paclitaxel plus carboplatin, Cet Cetuximab, PP Pemetrexed plus cisplatin, SP S1 plus cisplatin, NR Not reported 
preclinical study showed that endostatin plus anti-PD-1 also exerted a synergic effect on tumor growth in murine models of Lewis lung carcinoma by improving the TME and inducing autophagy [55]. An ongoing clinical trial (NCT04094909) is investigating the efficacy and safety of endostatin combined with chemotherapy and pembrolizumab as first-line therapy in patients with advanced or metastatic NSCLC. Despite the lack of clinical trials involving the combination therapy of endostatin, ICIs and RT/CRT, the synergic effect between endostatin and ICIs/RT will provide a potential way to improve clinical benefits for these patients when compared with current standard treatment.

\section{Conclusion}

Based on this pooled data analysis, adding recombinant human endostatin to radiotherapy or concurrent chemoradiotherapy is an effective and less toxic method for the treatment of patients with unresectable LA-NSCLC. We suggest that concurrent administration of endostatin and CRT or RT presents a promising treatment approach for some patients in the era when CRT plus durvalumab has become the current standard of care. For patients who cannot tolerate CCRT and ICIs, endostatin combined with RT alone may be a good alternative, but for those patients who can tolerate CCRT but cannot tolerate ICIs, addition of endostatin to CCRT may become a more effective treatment strategy. High-quality prospective studies are needed to validate this suggestion. Given the synergistic antitumor effect of antiangiogenic agents and RT/ICIs on lung cancer, triple- or quadruple- combination therapy of endostatin, ICIs and RT/CRT for patients with inoperable stage III NSCLC might become a potential strategy in the future. However, multiple challenges regarding this combination remain to be addressed before it can be applied to clinical practice.

\section{Abbreviations}

AEs: Adverse events; CCRT: Concurrent chemoradiotherapy; Cl: Confidence interval; CIV: Continuous intravenous pumping; CRT: Chemoradiotherapy; ECRT: Endostatin plus concurrent chemoradiotherapy; ERT: Endostatin plus radiotherapy; FDA: Food and Drug Administration; ICls: Immune checkpoint inhibitors; IV: Intravenous injection; LA-NSCLC: Locally advanced non-small cell lung cancer; LCR: Local control rate; NSCLC: Non-small cell lung cancer; ORR: Objective response rate; OS: Overall survival; PFS: Progression-free survival; PS: Performance status; RCTs: Randomized controlled trials; RT: Radiotherapy; TME: Tumor microenvironment; VEGF: Vascular endothelial growth factor; VEGFR: Vascular endothelial growth factor receptor

\section{Acknowledgments}

None.

\section{Authors' contributions}

All authors read and approved the final manuscript prior to submission. $\mathrm{CH}$ and JM conceived and designed the project; SZ, LS, and LH performed the project; SZ analyzed the data and wrote the paper; JM was the Senior Author who oversaw the project.

\section{Funding}

This study was supported by grants from the 345 Talent Project of Shengjing Hospital.

\section{Availability of data and materials}

The authors declare that all data generated or analyzed during this study are included in this article.

\section{Ethics approval and consent to participate}

All analyses were based on previously published studies, and hence no ethical approval and patient consent were required.

\section{Consent for publication}

Not applicable.

\section{Competing interests}

The authors declare that they have no competing interests.

Received: 14 November 2019 Accepted: 19 August 2020

Published online: 24 August 2020

\section{References}

1. Bray F, Ferlay J, Soerjomataram I, Siegel RL, Torre LA, Jemal A. Global cancer statistics 2018: GLOBOCAN estimates of incidence and mortality worldwide for 36 cancers in 185 countries. CA Cancer J Clin. 2018;68(6):394-424.

2. Wistuba II, Gelovani JG, Jacoby JJ, Davis SE, Herbst RS. Methodological and practical challenges for personalized cancer therapies. Nat Rev Clin Oncol. 2011:8(3):135-41.

3. Yang P, Allen MS, Aubry MC, Wampfler JA, Marks RS, Edell ES, et al. Clinical features of 5,628 primary lung cancer patients: experience at Mayo Clinic from 1997 to 2003. Chest. 2005;128(1):452-62.

4. Auperin A, Le Pechoux C, Rolland E, Curran WJ, Furuse K, Fournel P, et al. Meta-analysis of concomitant versus sequential radiochemotherapy in locally advanced non-small-cell lung cancer. J Clin Oncol. 2010;28(13):2181-90.

5. Curran WJ Jr, Paulus R, Langer CJ, Komaki R, Lee JS, Hauser S, et al. Sequential vs. concurrent chemoradiation for stage III non-small cell lung cancer: randomized phase III trial RTOG 9410. J Natl Cancer Inst. 2011; 103(19):1452-60.

6. Criss SD, Mooradian MJ, Sheehan DF, Zubiri L, Lumish MA, Gainor JF, et al. Costeffectiveness and Budgetary Consequence Analysis of Durvalumab Consolidation Therapy vs No Consolidation Therapy After Chemoradiotherapy in Stage III Non-Small Cell Lung Cancer in the Context of the US Health Care System. JAMA Oncol. 2019;5(3):358-65.

7. Uemura T, Hida T. Durvalumab showed long and durable effects after chemoradiotherapy in stage III non-small cell lung cancer: results of the PACIFIC study. J Thorac Dis. 2018;10(Suppl 9):S1108-S12.

8. Antonia SJ, Villegas A, Daniel D, Vicente D, Murakami S, Hui R, et al. Overall survival with Durvalumab after Chemoradiotherapy in stage III NSCLC. N Engl J Med. 2018;379(24):2342-50.

9. Toma-Dasu I, Dasu A, Karlsson M. The relationship between temporal variation of hypoxia, polarographic measurements and predictions of tumour response to radiation. Phys Med Biol. 2004:49(19):4463-75.

10. Seo Y, Yan T, Schupp JE, Colussi V, Taylor KL, Kinsella TJ. Differential radiosensitization in DNA mismatch repair-proficient and -deficient human colon cancer xenografts with 5-iodo-2-pyrimidinone-2'-deoxyribose. Clin Cancer Res. 2004;10(22):7520-8.

11. Ansiaux R, Baudelet C, Jordan BF, Crokart N, Martinive P, DeWever J, et al. Mechanism of reoxygenation after antiangiogenic therapy using SU5416 and its importance for guiding combined antitumor therapy. Cancer Res. 2006:66(19):9698-704.

12. Provencio $M$, Sanchez $A$. Therapeutic integration of new molecule-targeted therapies with radiotherapy in lung cancer. Transl Lung Cancer Res. 2014; 3(2):89-94.

13. Lind JS, Senan S, Smit EF. Pulmonary toxicity after bevacizumab and concurrent thoracic radiotherapy observed in a phase I study for inoperable stage III non-small-cell lung cancer. J Clin Oncol. 2012;30(8):e104-8.

14. Jiang XD, Dai P, Qiao Y, Wu J, Song DA, Li SQ. Clinical study on the recombinant human endostatin regarding improving the blood perfusion and hypoxia of non-small-cell lung cancer. Clin Transl Oncol. 2012;14(6):437-43. 
15. Meng MB, Jiang XD, Deng $L$, Na FF, He JZ, Xue JX, et al. Enhanced radioresponse with a novel recombinant human endostatin protein via tumor vasculature remodeling: experimental and clinical evidence. Radiother Oncol. 2013;106(1):130-7.

16. Jiang $X D$, Dai $P, W u$ J, Song DA, Yu JM. Effect of recombinant human endostatin on radiosensitivity in patients with non-small-cell lung cancer. Int J Radiat Oncol Biol Phys. 2012;83(4):1272-7.

17. Jiang X, Guan W, Li M, Liang W, Qing Y, Dai N, et al. Endostatin combined with platinum-based chemo-radiotherapy for advanced non-small cell lung cancer. Cell Biochem Biophys. 2015;71(2):571-7.

18. Zhai YR, Hui Z, Ma H, Zhao L, Li D, Liang J, et al. HELPER study: a phase II trial of continuous infusion of endostar combined with concurrent etoposide plus cisplatin and radiotherapy for treatment of unresectable stage III non-small-cell lung cancer. Radiother Oncol. 2019;131:27-34.

19. Jadad ARMR, Carroll D, Jenkinson C, Reynolds DJ, Gavaghan DJ, McQuay HJ. Assessing the quality of reports of randomized clinical trials: is blinding necessary? Control Clin Trials. 1996;17(1):1-12.

20. Wells GA SB, O'Connell D, Peterson J, Welch V, Losos M, Tugwell P. The Newcastle-Ottawa Scale (NOS) for assessing the quality of nonrandomised studies in meta-analyses. Ottawa Hospital Research Institute website. http://www.ohri.ca/programs/clinical_epidemiology/ oxford.asp. [updated 2015/12/29.

21. Sun XJ, Deng $Q H, Y u X M$, Ji YL, Zheng YD, Jiang $H$, et al. A phase II study of Endostatin in combination with paclitaxel, carboplatin, and radiotherapy in patients with unresectable locally advanced non-small cell lung cancer. BMC Cancer. 2016;16:266

22. Bao Y, Peng F, Zhou QC, Yu ZH, Li JC, Cheng ZB, et al. Phase II trial of recombinant human endostatin in combination with concurrent chemoradiotherapy in patients with stage III non-small-cell lung cancer. Radiother Oncol. 2015;114(2):161-6.

23. Tang H, Ma H, Peng F, Bao Y, Hu X, Wang J, et al. Prognostic performance of inflammation-based prognostic indices in locally advanced non-smalllung cancer treated with endostar and concurrent chemoradiotherapy. Mol Clin Oncol. 2016:4(5):801-6.

24. Wen C, Zhang LZ. The observation of short-term effects of $\mathrm{YH}-16$ combined with concurrent three dimensional conformal radiotherapy on LocallyAdvancedNon-small cell lung Cancer. J Basic Clin Oncol. 2009;22(3): 218-20.

25. Chen Q, Shi Q, Xie Q. Preliminary study of recombinant human endostatin(Endostar)combined with concurrent intensity-modulated radiation therapy for inoperable local advanced non-small cell lung cancer in elderly patients. Chin J of Oncol Prev and Treat. 2017;9(2):132-45.

26. Ma JT, Sun J, Sun L, Zhang SL, Huang LT, Han CB. Efficacy and safety of apatinib in patients with advanced nonsmall cell lung cancer that failed prior chemotherapy or EGFR-TKIs: a pooled analysis. Medicine (Baltimore). 2018;97(35):e12083.

27. Weidner N, Semple JP, Welch WR, Folkman J. Tumor angiogenesis and metastasis--correlation in invasive breast carcinoma. N Engl J Med. 1991; 324(1):1-8.

28. Ingber D, Fujita T, Kishimoto S, Sudo K, Kanamaru T, Brem H, et al. Synthetic analogues of fumagillin that inhibit angiogenesis and suppress tumour growth. Nature. 1990;348(6301):555-7.

29. Bae DG, Gho YS, Yoon WH, Chae CB. Arginine-rich anti-vascular endothelial growth factor peptides inhibit tumor growth and metastasis by blocking angiogenesis. J Biol Chem. 2000;275(18):13588-96.

30. Vasudev NS, Reynolds AR. Anti-angiogenic therapy for cancer: current progress, unresolved questions and future directions. Angiogenesis. 2014; 17(3):471-94.

31. Sunshine SB, Dallabrida SM, Durand E, Ismail NS, Bazinet L, Birsner AE, et al. Endostatin lowers blood pressure via nitric oxide and prevents hypertension associated with VEGF inhibition. Proc Natl Acad Sci U S A. 2012;109(28): 11306-11

32. Li J, Qin S, Xu J, Xiong J, Wu C, Bai Y, et al. Randomized, double-blind, placebo-controlled phase III trial of Apatinib in patients with chemotherapy-refractory advanced or metastatic adenocarcinoma of the stomach or Gastroesophageal junction. J Clin Oncol. 2016;34(13):1448-54.

33. Klein A, Loewenstein A. Therapeutic monoclonal antibodies and fragments: Bevacizumab. Dev Ophthalmol. 2016;55:232-45.

34. Rong B, Yang S, Li W, Zhang W, Ming Z. Systematic review and metaanalysis of Endostar (rh-endostatin) combined with chemotherapy versus chemotherapy alone for treating advanced non-small cell lung cancer. World J Surg Oncol. 2012;10:170.

35. Garon EB, Ciuleanu TE, Arrieta O, Prabhash K, Syrigos KN, Goksel T, et al. Ramucirumab plus docetaxel versus placebo plus docetaxel for second-line treatment of stage IV non-small-cell lung cancer after disease progression on platinum-based therapy (REVEL): a multicentre, double-blind, randomised phase 3 trial. Lancet. 2014;384(9944):665-73.

36. Brizel DM, Sibley GS, Prosnitz LR, Scher RL, Dewhirst MW. Tumor hypoxia adversely affects the prognosis of carcinoma of the head and neck. Int J Radiat Oncol Biol Phys. 1997;38(2):285-9.

37. Brizel DM, Hage WD, Dodge RK, Munley MT, Piantadosi CA, Dewhirst MW. Hyperbaric oxygen improves tumor radiation response significantly more than carbogen/nicotinamide. Radiat Res. 1997;147(6):715-20.

38. Sonveaux P. Provascular strategy: targeting functional adaptations of mature blood vessels in tumors to selectively influence the tumor vascular reactivity and improve cancer treatment. Radiother Oncol. 2008;86(3):300-13.

39. Peng $Q$, Li M, Wang Z, Jiang $M$, Yan X, Lei S, et al. Polarization of tumorassociated macrophage is associated with tumor vascular normalization by endostatin. Thorac Cancer. 2013;4(3):295-305.

40. Wu JB, Tang YL, Liang XH. Targeting VEGF pathway to normalize the vasculature: an emerging insight in cancer therapy. Onco Targets Ther. 2018;11:6901-9.

41. Bradley JD, Paulus R, Komaki R, Masters G, Blumenschein G, Schild S, et al. Standard-dose versus high-dose conformal radiotherapy with concurrent and consolidation carboplatin plus paclitaxel with or without cetuximab for patients with stage IIIA or IIIB non-small-cell lung cancer (RTOG 0617): a randomised, two-by-two factorial phase 3 study. Lancet Oncol. 2015;16(2): 187-99.

42. Senan S, Brade A, Wang LH, Vansteenkiste J, Dakhil S, Biesma B, et al. PROCLAIM: randomized phase III trial of Pemetrexed-Cisplatin or EtoposideCisplatin plus thoracic radiation therapy followed by consolidation chemotherapy in locally advanced nonsquamous non-small-cell lung Cancer. J Clin Oncol. 2016;34(9):953-62.

43. Liang J, Bi N, Wu S, Chen M, Lv C, Zhao L, et al. Etoposide and cisplatin versus paclitaxel and carboplatin with concurrent thoracic radiotherapy in unresectable stage III non-small cell lung cancer: a multicenter randomized phase III trial. Ann Oncol. 2017;28(4):777-83.

44. Sasaki T, Seto T, Yamanaka T, Kunitake N, Shimizu J, Kodaira T, et al. A randomised phase II trial of S-1 plus cisplatin versus vinorelbine plus cisplatin with concurrent thoracic radiotherapy for unresectable, locally advanced non-small cell lung cancer: WJOG5008L. Br J Cancer. 2018;119(6): 675-82.

45. National Comprehensive Cancer Network. NCCN clinical practice guidelines in Oncology: Non-Small Cell Lung Cancer(2020.V6) [Available from: https:// www.ncen.org/professionals/physician_gls/default.aspx\#nscl.

46. Lin SH, Lin Y, Yao L, Kalhor N, Carter BW, Altan M, et al. Phase II trial of concurrent Atezolizumab with Chemoradiation for Unresectable NSCLC. J Thorac Oncol. 2020;15(2):248-57.

47. Peters S, Ruysscher DD, Dafni U, Felip E, Guckenberger M, Vansteenkiste JF, et al. Safety evaluation of nivolumab added concurrently to radiotherapy in a standard first line chemo-RT regimen in unresectable locally advanced NSCLC: The ETOP NICOLAS phase II trial. Lung Cancer. 2018;36(15_suppl): 8510.

48. Al-Shamsi HO, Al Farsi A, Ellis PM. Stage III non-small-cell lung cancer: establishing a benchmark for the proportion of patients suitable for radical treatment. Clin Lung Cancer. 2014;15(4):274-80.

49. Jiang XD, Qiao Y, Dai P, Chen Q, Wu J, Song DA, et al. Enhancement of recombinant human endostatin on the radiosensitivity of human pulmonary adenocarcinoma A549 cells and its mechanism. J Biomed Biotechnol. 2012:2012:301931.

50. Travis WDCT, Corrin B, et al. In Collaboration with L.H. Sobin and Pathologists from 14 Countries. Histological Typing of Lung and Pleural Tumours (International Histological Classification of Tumours). Geneva: World Health Organization; 1999. p. 1-55.

51. Cheng Y, Nie L, Liu Y, Jin Z, Wang X, Hu Z. Comparison of Endostar continuous versus intermittent intravenous infusion in combination with first-line chemotherapy in patients with advanced non-small cell lung cancer. Thorac Cancer. 2019;10(7):1576-80.

52. Honglian M, Zhouguang $H$, Fang $P$, Lujun Z, Dongming L, Yujin $X$, et al. Different administration routes of recombinant human endostatin combined with concurrent chemoradiotherapy might lead to different 
efficacy and safety profile in unresectable stage III non-small cell lung cancer: updated follow-up results from two phase II trials. Thorac Cancer. 2020;11(4):898-906.

53. Huang Y, Yuan J, Righi E, Kamoun WS, Ancukiewicz M, Nezivar J, et al. Vascular normalizing doses of antiangiogenic treatment reprogram the immunosuppressive tumor microenvironment and enhance immunotherapy. Proc Natl Acad Sci U S A. 2012;109(43):17561-6.

54. Socinski MA, Jotte RM, Cappuzzo F, Orlandi F, Stroyakovskiy D, Nogami N, et al. Atezolizumab for first-line treatment of metastatic nonsquamous NSCL C. N Engl J Med. 2018;378(24):2288-301.

55. Wu J, Zhao X, Sun Q, Jiang Y, Zhang W, Luo J, et al. Synergic effect of PD-1 blockade and endostar on the PI3K/AKT/mTOR-mediated autophagy and angiogenesis in Lewis lung carcinoma mouse model. Biomed Pharmacother. 2020;125:109746.

\section{Publisher's Note}

Springer Nature remains neutral with regard to jurisdictional claims in published maps and institutional affiliations.

Ready to submit your research? Choose BMC and benefit from:

- fast, convenient online submission

- thorough peer review by experienced researchers in your field

- rapid publication on acceptance

- support for research data, including large and complex data types

- gold Open Access which fosters wider collaboration and increased citations

- maximum visibility for your research: over $100 \mathrm{M}$ website views per year

At $\mathrm{BMC}$, research is always in progress.

Learn more biomedcentral.com/submissions 